小学校高学年児童における運動機能とローレル指数, 身体活動量との関連性 小林 壮太 $^{1,2^{*}}$, 長谷川 智 ${ }^{1,2}$, 渡辺 真樹 ${ }^{1}$, 柳澤 正 $^{1}$, 竹原 健 $^{1}$, 妇田 滋 $^{2}$

\title{
The relationship of the Rohrer index and physical activity on motor function in upper elementary school children
}

\author{
Sota Kobayashi ${ }^{12^{*}}$, Satoshi Hasegawa ${ }^{1,2}$, Masaki Watanabe ${ }^{1}$, Tadashi Yanagisawa ${ }^{1}$, \\ Ken Takehara ${ }^{1}$ and Shigeru Usuda ${ }^{2}$ \\ 1公立七日市病院， ₹370-2343 群馬県富阔市七日市643 (Public Nanokaichi Hospital, 643 Nanokaichi, Tomioka, Gunma \\ 370-2343, Japan) \\ 2群馬大学大学院保健学研究科, ₹371-8514 群馬県前橋市昭和町3-39-22 (Gunma University Graduate School of Health \\ Science, 3-39-22 Showa, Maebashi, Gunma 371-8514, Japan)
}

Received: November 28, 2020 / Accepted: January 21, 2021

\begin{abstract}
The purpose of this study was to examine the relationship of the Rohrer index and physical activity on motor function. The subjects were 143 elementary school children in the 5 th and 6th grades. Motor function was measured based on musculoskeletal examination. The Rohrer index was calculated from height and weight, and $\geq 140$ was defined as a tendency to be overweight. Physical activity was investigated using a self-reported questionnaire, the WHO Health Behaviour in School-aged Children in Japanese version (HBSC-J). A total of 130 students and their parents agreed to participate in this study, and the data of 127 students were analyzed. The main results were as follows: 26 students had a Rohrer index $\geq 140$, and 60 students $(47.2 \%)$ had abnormalities in one or more items of motor function. In particular, there were many who reported "Impossible to fully squat" and "Limitation of standing forward flexion". When compared by sex, "Impossible to fully squat", "Limitation of standing forward flexion", and "Pain in shoulder" were particularly frequent in boys. The Rohrer index was particularly high in those who reported that it was "Impossible to fully squat", but it was not associated with HBSC-J. "Impossible to fully squat" was particularly low in HBSC-J (days of Moderate to vigorous Physical Activity and frequency of Vigorous Physical Activity). The results suggested that children of impossible to fully squat is a lot of low activity and obesity. In conclusion, children who are unable to squat should be followed up to promote physical activity and improve obesity.
\end{abstract}

Jpn J Phys Fitness Sports Med, 70(2): 181-188 (2021)

Keywords : children, physical activity, body measure, obesity, cross sectional studies

\section{緒言}

児童において身体活動量を高めることは重要視され 世界各国でガイドラインが示されている1-4)。本邦では 近年，児童に関する健康問題として運動不足と運動過多 の二極化傾向にあり，健全な運動器の発達の阻害への影 響について問題視されている ${ }^{5,6)}$. 運動不足の児童につ いて，スポーッ庁や笹川スポーツ財団による調査では, ほとんど運動をしていない児童は約 $10 \%$ 存在すると報 告されている7,8). 運動過多の览童については笹川スポー ツ財団の調查で 10 代の約 4 割が週 7 日以上運動してお り, 週 7 日以上運動している者の約 $70 \%$ は 5 種目以上実

*Correspondence: h181c003@gunma-u.ac.jp
施していると報告されている ${ }^{8)}$. 二極化傾向などの問題 に対して,「運動器の 10 年」日本委員会は,「学校にお ける運動器検診体制の整備・充実モデル事業」によって 2005 年から 2010 年まで計 10 道府県で運動器検診の取り 組みを実施し，2014年に文部科学省は学校保健安全法施 行規則を一部改正し，児童の健康診断の項目として「四 肢の状態」が必須化され，2016年から運動器検診が開始 された ${ }^{9,10)}$ ，運動器検診は運動器保健調查票による事前 調査と学校医による健康診断時に調査が行われ, 事後措 置が必要な場合には医療機関を受診する手順で実施さ

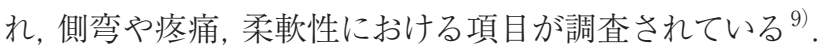

運動器検診に関する報告では, 学年が上がるにつれて 有病率が増加し, さらに, 運動部所属児童で有病率が高 いことが報告されている ${ }^{11,12)}$ 。また, 疼痛に関しては, 
運動時間が長く, Body Mass Index（BMI）が高いほど疼 痛を有すること ${ }^{13)}$ ，柔軟性に関連するしゃがみ込みにつ いて, 踵接地が困難な览童ではローレル指数が高いこと が報告されている ${ }^{14)}$. しかしながら, 運動器検診に関連 した報告はこれらが散見される程度で, 報告数が少ない． また，運動不足は身体の硬さ・タイトネスといった運動 機能不全の原因の 1 つとして考えられている ${ }^{9)}$ が, 活動 量と運動器検診の動作の関連性は検討されていない。こ れらの関連性を検討し報告することは, 日常的な動作が 困難な坚童の課題解決の一助となると考えられる.

本研究は, 小学校高学年の児童の運動機能とローレル指 数, 身体活動量との関連性を検討することを目的とした。

\section{方法}

研究デザイン 本研究のデザインは, 横断研究とした.

対象 群馬県 $\mathrm{T}$ 市の小学校 1 校の全 5,6 年生 143 名を 対象とした. 2015年度国勢調查 ${ }^{15)}$ によると, 本研究の対 象小学校が位置する群馬県 T市は総人口49746名（男性 24323 名, 女性 25423 名), 15歳未満の人口は 6037 (12.1\%) であり，男児 3107 名 $(51.5 \%)$ ，女児 2930 名 (48.5\%) で ある。また， T市教育委員会 ${ }^{16)}$ によると2019年 5 月時点 で市内公立小学校全 11 校の览童数は 2327 名で本研究の 対象となった小学校は 462 名 (19.9\%) と市内児童数の約 20\%を占める小学校である.

研究の実施にあたって, 対象者が通う小学校の学校長 および養護教諭に調查協力を依頼し，協力の同意を得た． 同意が得られた後，2019年 5 月上旬に説明文書を含ん だ同意書および質問紙を各家庭に配布し，2019年 5 月 中旬に養護教諭を介して質問紙を回収した。本人と保護 者の書面での同意かつ質問紙の回収が得られた対象に 2019年 5 月下旬〜 6 月上旬に運動機能測定を実施した。 質問紙の調査内容は自記式にて基本情報, 身体活動量を 調査しプライバシー保護のため無記名とした。運動機能 測定は測定者が対象者に接触しないよう, 動作の模倣や 聴取にて実施した。運動機能測定は内科検診と同日に行 われ，測定は理学療法士 2 名にて実施した。本研究の実 施に際し, 公立七日市病院の倫理審査委員会の承認を得 た上で実施した（承認番号20180120）。

\section{調査項目}

基本特性 基本情報として性別, 身長, 体重について調査 した，得られた身長，体重から [体重 $(\mathrm{kg}) \div$ 身長 $(\mathrm{cm})^{3} \times$ $\left.10^{7}\right]$ の式を用いてローレル指数を算出した。ローレル指 数は小中学生で使用される体格指数であり, 標準体重が 不明であっても身長㧍よび体重で算出が可能である ${ }^{17) .}$ 結果の解釈としては，140１59を過体重，160以上を肥 満と判定されている ${ }^{17,18)}$. 本研究では 140 以上を肥満傾
向に判別した.

身体活動量調查览童の身体活動量調查のために Tanakaら ${ }^{19)} に よ っ て 日$ 本語版の翻訳がなされている自 記式質問紙の青少年健康行動質問票（Health Behavior School Children in Japanese version: HBSC-J）を用い た．HBSC-Jでは身体活動を「心臓がドキドキしたり息 切れしたりするようなすべての活動」と定義しており， スポーツや友達と遊ぶこと, 学校へ徒歩で通うことも含 めている. 質問項目は中高強度の身体活動に関する日数, 高強度の身体活動に関する頻度, 時間の 3 項目で構成 されている. 中高強度 (Moderate to vigorous Physical Activity：MVPA）の日数は「最近 7 日間に 1 日当たり 少なくとも合計 60 分間の身体活動をした日数」を「0日」, $\lceil 1$ 日」,「 2 日」, 「 3 日」, 「 4 日」, 「 5 日」, 「 6 日」,「 7 日」 の 8 段階, 高強度 (Vigorous Physical Activity: VPA)の 頻度は「息切れしたり汗をかいたりするくらいの運動の 回数」を「まったくしない」,「月に 1 回未満」,「月に 1 回」,「週に 1 回」,「週に $2 \sim 3$ 回」,「週に $4 \sim 6$ 回」,「毎 日」の 7 段階，VPAの時間は「息切れしたり汗をかい たりするくらいの運動を 1 週間に何時間するか」を「ぜ んぜんしない」，「执よそ30分」，「およそ1時間」，「拉よ そ $2 \sim 3$ 時間」，「およそ $4 \sim 6$ 時間」，「およそ 7 時間以 上」の 6 段階にて評定した。解析時にはMVPAの日数 を「0（０日）〜 7 （7日）」，VPAの頻度を「1（まっ たくしない)〜 7 (毎日)」, VPAの時間を「1（ぜんぜ んしない)～6（およそ7時間以上）」と各質問項目の低 活動にあたる項目を低值とした順序尺度として数值化 し, 解析した。また, 先行研究 ${ }^{20-22}$ を参考に, VPAの 頻度が「週に $2 \sim 3$ 回」以上, かつVPAの時間が「お よそ 1 時間」以上と回答した者を「Active」，それ以外 のVPAの頻度が「週に 1 回以下」あるいはVPAの時間 が「㧍よそ30分」以下と回答した者を「Inadequately active (Inactive)」の 2 群に分類した.

運動機能測定 運動機能測定は, 群馬県運動器検診マ ニュアルの評価方法 ${ }^{23)}$ ，林による調查方法 ${ }^{24)}$ を参考に, 運動機能とオーバーユースに関した測定を実施した。運 動機能の項目として片脚立ち，しゃがみ込み，肩関節可 動域, 肘関節可動域, 前屈での指先接地の動作遂行の可 否を測定した（Table 1)。オーバーユースの項目として は肩関節痛, 时関節痛, 膝下痛, 前屈痛, 後屈痛におい ての疼痛の有無を調査した。

統計解析 統計処理にはIBM.SPSS 25.0を用いた. 全ての 項目に扔いて, Shapiro-Wilk検定に扔いて正規性の確認 を行った結果, 正規性が確認された変数にはパラメトリッ ク検定, 正規性が確認されなかった変数はノンパラメト リック検定を用いた，身体活動量は性差があることが報

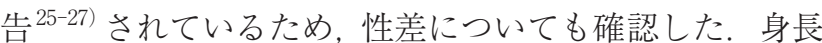


のみ正規性が確認されたため, 身長の性差は $\mathrm{t}$ 検定を実 施した. 身体活動量, 体重, ローレル指数と性差の関連性, 身体活動量の 2 群 (Active 群, Inactive 群) とローレル指 数の関連性, 運動機能とローレル指数の関連性, 運動機 能と身体活動量の関連性についてMann-WhitneyのU検 定を実施した。学年, 肥満傾向の有無, 身体活動量の 2 群 (Active 群, Inactive群), 運動機能に関する性差, 身体活 動量, 身体機能に関する肥満傾向の有無, 運動機能と身 体活動量の 2 群 (Active 群, Inactive群) に関する関連性 については $\chi^{2}$ 検定を実施した。統計学的有意水準は $5 \%$ とした. なお, 分析対象者のうち, 質問紙にて一部空白が みられた項目については, 久損值として分析した。

\section{結 果}

研究フローチャートをFig. 1に示した。対象者143名 中, 質問紙の回収および同意が得られた対象は 130 名（回 収率 $90.9 \%$ ) であった。解析は運動機能測定の未実施者, 質問紙による性別未記入者の計 3 名を除外した 127 名
（5 年64名，6年63名）で実施した。Table 2 に対象者基 本情報を示した。本研究の対象者の体格は男子が身長 $140.6 \pm 7.3 \mathrm{~cm}$ ，体重33.3［30.6～38.8］ kg，女子が 143.0 $\pm 7.5 \mathrm{~cm}$, 体重 35.0 [30.6 44.0]，ローレル指数が 140 以上の者は26名, 140 未満は99名で体格に性差を認めな かった。身体活動量はActive群が68名, Inactive群が 55 名で性差は認めなかった. Table 3 に運動機能測定結 果を示した。運動機能測定の項目中 1 つ以上で不可ある いは疼痛ありが含まれた対象は60名 $(47.2 \%)$ であった。 項目の中で, しゃがみ込み不可者は27名 (21.3\%), 前屈 での指先接地不可者は38名 $(29.9 \%)$ と該当者が多かった。 測定項目の内，しゃがみ込み不可，前屈での指先接地不 可, 肩関節の疼痛で性差を認め男子で有意に多かった。

Table 4 に身体活動量とローレル指数との関連性を示 した. Active群 120.8 [114.9〜 131.7], Inactive 群 122.5 [113.2〜 145.2] であり 2 群間に有意な差を認めなかった。 また，ローレル指数と肥満傾向の有無に関してはActive 群の内ローレル指数が 140 以上は 11 名 $(8.9 \%), 140$ 未満

Table 1. The criteria of impossible evaluation of motor function assessment.

\begin{tabular}{ll}
\hline \multicolumn{1}{c}{ Assessement } & \multicolumn{1}{c}{ The criteria for impossible evaluation } \\
\hline (1) Standing on one leg & Impossible to stand without swaying for more than 5 seconds. \\
(2) Fully squat & $\begin{array}{l}\text { Impossible to fully squat without heel lifting. } \\
\text { Fall down to back before fully squat. }\end{array}$ \\
(3) Range of motion of the shoulder & Impossible to perform shoulder flexion until $180^{\circ}$. \\
(4) Range of motion of the elbow & Impossible to perform full flexion or extension. \\
(5) Standing forward flextion & Impossible to touch the floor in the standing position with strai
\end{tabular}

(Created based on motor medical examination manual from Gunma and previous research for Hayashi)

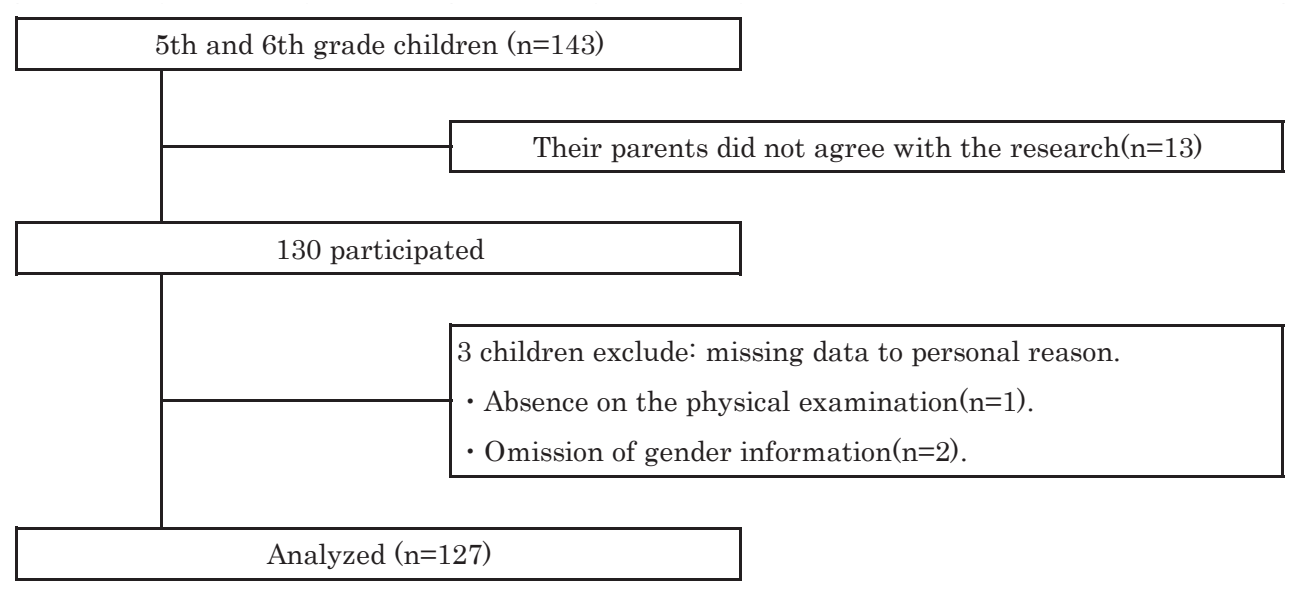

Fig. 1 Follow-up flow diagram 
Table 2. Demographic distribution and physical activity and its gender diffrencess

\begin{tabular}{|c|c|c|c|c|}
\hline & $\begin{array}{c}\text { All } \\
(\mathrm{n}=127)\end{array}$ & $\begin{array}{l}\text { Boys } \\
(n=53)\end{array}$ & $\begin{array}{c}\text { Girls } \\
(\mathrm{n}=74)\end{array}$ & $\mathrm{p}$ \\
\hline \multicolumn{5}{|l|}{ Grade, $n(\%)$} \\
\hline 5th & $64(50.4)$ & $27(21.3)$ & $37(29.1)$ & \multirow{2}{*}{0.916} \\
\hline 6 th & $63(49.6)$ & $26(20.5)$ & $37(29.1)$ & \\
\hline \multicolumn{5}{|c|}{ Self-reported PA from the HBSC-J, Median[IQR], n(\%) } \\
\hline Days of at least $60 \mathrm{~min} /$ day MVPA & $3[2 \sim 5]$ & $4[2 \sim 5]$ & $3[2 \sim 5]$ & 0.176 \\
\hline Frequency of VPA & $5[4 \sim 6]$ & $5[4 \sim 6]$ & $5[4 \sim 6]$ & 0.086 \\
\hline Duration of VPA & $3[2 \sim 5]$ & $4[2 \sim 5]$ & $3[2 \sim 4]$ & 0.278 \\
\hline Active & $68(55.3)$ & $28(52.8)$ & $40(54.1)$ & \multirow{2}{*}{0.943} \\
\hline Inactive & $55(44.7)$ & $23(43.4)$ & $32(43.2)$ & \\
\hline \multicolumn{5}{|l|}{ Physique, Mean \pm SD, Median[IQR], n(\%) } \\
\hline Height $(\mathrm{cm})$ & $142.0 \pm 7.5$ & $140.6 \pm 7.3$ & $143.0 \pm 7.5$ & 0.571 \\
\hline Weight(kg) & $34.7[30.6 \sim 40.6]$ & $33.3[30.6 \sim 38.8]$ & $35.0[30.6 \sim 44.0]$ & 0.195 \\
\hline Rohrer index, Median & $121.0[113.9 \sim 135.5]$ & $121.1[113.3 \sim 134.0]$ & $120.7[114.4 \sim 136.3]$ & 0.830 \\
\hline$<140$ & $99(79.2)$ & $41(32.8)$ & $58(46.4)$ & \multirow{2}{*}{0.663} \\
\hline$\geq 140$ & $26(20.8)$ & $12(9.6)$ & $14(11.2)$ & \\
\hline
\end{tabular}

PA: Physical activity, HBSC-J: Health Behavior School Children in Japanese version, MVPA: Moderate to vigorous PA, VPA: Vigorous PA.

Table 3. Comparison of physical function measurement by gender

\begin{tabular}{|c|c|c|c|c|}
\hline & $\begin{array}{c}\text { All } \\
(\mathrm{n}=127)\end{array}$ & $\begin{array}{c}\text { Boys } \\
(\mathrm{n}=53)\end{array}$ & $\begin{array}{c}\text { Girls } \\
(\mathrm{n}=74)\end{array}$ & $\mathrm{p}$ \\
\hline Impossible to stand on one foot for 5 seconds & $4(3.1)$ & $2(3.8)$ & $2(2.7)$ & 1.000 \\
\hline Impossible to fully squat & $27(21.3)$ & 16(30.2) & $11(14.9)$ & 0.037 \\
\hline Limited range of motion of the shoulder & $1(0.8)$ & $0(0)$ & $1(1.3)$ & 1.000 \\
\hline Limited range of motion of the elbow & $0(0)$ & $0(0)$ & $0(0)$ & - \\
\hline Limitation of standing forward flexion & $38(29.9)$ & $24(45.3)$ & $14(19.2)$ & 0.001 \\
\hline Pain in shoulder & 6(4.7) & 6(11.3) & $0(0)$ & 0.004 \\
\hline Pain in elbow & $2(1.6)$ & $2(3.8)$ & $0(0)$ & 0.172 \\
\hline Pain in Below-knee & $0(0)$ & $0(0)$ & $0(0)$ & - \\
\hline Pain in a forward bend & $0(0)$ & $0(0)$ & $0(0)$ & - \\
\hline Pain in a back bend & $4(3.1)$ & $2(3.8)$ & $2(2.7)$ & 1.000 \\
\hline
\end{tabular}

は58名 $(46.8 \%)$, Inactive 群の内ローレル指数が 140 以 上は 15 名 (12.1\%), 140未満は40名 (32.3\%)であり各群 間に有意な関連性を認めなかった。

運動機能測定の結果からしゃがみ込みおよび前屈での 指先接地以外の項目にて該当者が少数であったため, こ の 2 項目に関してのみ肥満傾向および身体活動量との関 連性を分析した（Table 5)。ローレル指数はしゃがみ込 み可能者で120.5［113.6～130.8］，しゃがみ込み不可者 で131.4［118.6１50.6］でしやがみ込み不可者でローレ ル指数が高い傾向を示した。また，しゃがみ达み可能者 の内ローレル指数 140 以上であった者は 15 名（11.8\%）， 140 未満は 85 名 $(65.9 \%)$ であり，しゃがみ込み不可者は ローレル指数 140 以上であった者は 11 名 (8.7\%)，140未 満は16名 $(12.6 \%)$ であり，しゃがみ込みの可否と肥満
傾向の有無との間に有意な関連を示した。ローレル指数 と前屈の指先接地の可否との関連では有意な関連を認め なかった。

Table 6に身体活動量としゃがみ込みの可否, 前屈で の指先接地の可否との関連性を示した。しゃがみ込み不 可の者にHBSC-JのMVPAの日数, VPAの頻度の項目 で有意に低值を示したが, Active/Inactiveの 2 群間では 有意な関連性を認めなかった。前屈での指先接地の可否 は全ての項目で有意な関連を認めなかった。

\section{考察}

本研究の目的は, 運動器検診に関連した運動機能と ローレル指数，身体活動量との関連性を検討することで あった。本研究では，ローレル指数としゃがみ込みの間 
に有意な関連性を認め, 身体活動量との関連性としては, HBSC-JのMVPAの日数, VPAの頻度の項目で有意な 関連を認めたが, Active/Inactiveの 2 群間では有意な関 連性を認めなかった。運動器検診に関した報告は該当者 数を調査した報告が多く, 我々が知る限り, 運動器検診 に関連した運動機能と身体活動量との関連性を検討した 報告は初めてである.

本研究の対象者特性 本研究では運動機能の項目で 1 つ 以上該当した者は 60 名 $(47.2 \%)$ であった。先行研究で は，39.5\%〜 76.7\%と報告者によって該当率は異なって いるが28-30), 本研究の該当率も先行研究の該当率の中に 含まれる比率であった。項目に関しては, しゃがみ込み 不可者が 27 名 $(21.3 \%)$, 前屈での指先接地不可者が 38 名 $(29.9 \%)$ と該当者が多く, その他の項目は少ない傾向 を示した，報告されている知見では，しゃがみ达み不可 者に関しては小学校 1 年生と 6 年性で $10.1 \%{ }^{29)}$, 小学校 高学年児童で $28 \%$ であった ${ }^{31)}$ といったことや前屈にて 床に手がつかない児童において小学校 6 年生で前屈にて 床に手がつかない児童が $53.4 \%{ }^{29)}$ ，小学校 $5 ， 6$ 年生で
15.8\%であった ${ }^{32)} こ と ，$ 片脚立ちおよび上肢可動域制限 があった者は小学校 1 年生と 6 年生で $1.4 \%{ }^{29)}$ との知見 が明らかとなっており本研究との結果は大きな差異はな かった。したがって本研究の対象者の運動機能は一般的 な学童期の対象者であると考えられた。また，しゃがみ 込み, 前屈での指先接地, 肩関節痛において性差を認め た. 先行研究として，小学生においてしゃがみ达みに関 する足関節可動域制限, 前屈制限, 運動器の疼痛に男子

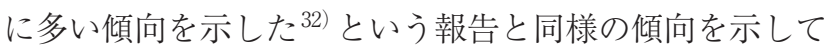
いた。

体格に関しては, 文部科学省の学校保健統計による と本研究と同年代の年齢別平均值は男子が身長 139.0 $145.2 \mathrm{~cm}$, 体重34.4 38.7 kg, 女子では 140.2 $146.6 \mathrm{~cm}$, $34.2 \sim 39.0 \mathrm{~kg}$ と報告している ${ }^{33)}$. 本研究の対象者では, 男子は同年代よりやせ型な児童，女子は同年代と平均的 な児童で構成されていたと考えられる。

身体活動量はHBSC-Jを使用し調査した結果，中央值 にてMVPAの日数「3日」, VPAの頻度「週に $2 \sim 3$ 回」, 時間「およそ1時間」であり，VPAの頻度および時間を 基に分類したActive群は55\%（男子52\%，女子54\%）で

Table 4. Comparison of Rohrer index by physical activity from HBSC-J

\begin{tabular}{crrr}
\hline & \multicolumn{2}{c}{ Self-reported PA from the HBSC-J } & \\
\cline { 2 - 3 } & \multicolumn{2}{c}{ Active } & \multicolumn{1}{c}{ Inactive } \\
\hline Rohrer Index & $120.8[114.9 \sim 131.7]$ & $122.5[113.2 \sim 145.2]$ & 0.898 \\
$<140$ & $58(46.8)$ & $40(32.3)$ & \\
$\geq 140$ & $11(8.9)$ & $15(12.1)$ & 0.124 \\
\hline
\end{tabular}

HBSC-J: Health Behavior School Children in Japanese version, PA: Physical activity. Median $[\mathrm{IQR}], \mathrm{n}(\%)$

Table 5. Comparison of Rohrer index by fully squat and touch the floor in the standing forward flextion

\begin{tabular}{|c|c|c|c|c|c|c|}
\hline & \multicolumn{2}{|c|}{ Fully squat } & \multirow[b]{2}{*}{$\mathrm{p}$} & \multicolumn{3}{|c|}{ Touch the floor in the standing forward flexion } \\
\hline & Possible & Impossible & & Possible & Impossible & $\mathrm{p}$ \\
\hline Rohrer Index & $120.5[113.6 \sim 130.8]$ & $131.4[118.6 \sim 150.6]$ & 0.025 & $120.73[114.5 \sim 133.8]$ & $121.1[110.6 \sim 145.6]$ & 0.911 \\
\hline$<140$ & $85(65.9)$ & 16(12.6) & 0003 & $74(58.3)$ & $27(21.3)$ & 0240 \\
\hline$\geq 140$ & 15(11.8) & $11(8.7)$ & 0.000 & 16(12.6) & $10(7.9)$ & 0.240 \\
\hline
\end{tabular}

Table 6. Comparison of PA by fully squat and touch the floor in the standing forward flextion

\begin{tabular}{|c|c|c|c|c|c|c|}
\hline & \multicolumn{2}{|c|}{ Fully squat } & \multirow[b]{2}{*}{$\mathrm{p}$} & \multicolumn{3}{|c|}{ Touch the floor in the standing forward flexion } \\
\hline & Possible & Impossible & & Possible & Impossible & $\mathrm{p}$ \\
\hline \multicolumn{7}{|l|}{ Self-reported PA from the HBSC-J } \\
\hline Days of at least $60 \mathrm{~min} /$ day MVPA(days/week) & $4[2 \sim 5]$ & $2[1 \sim 3.5]$ & 0.010 & $3[2 \sim 5]$ & $4[2 \sim 6]$ & 0.479 \\
\hline Frequency of VPA(days/week) & $5[4 \sim 6]$ & $5[3 \sim 5]$ & 0.022 & $5[4 \sim 6]$ & $5[3.5 \sim 6]$ & 0.413 \\
\hline Duration of VPA(hours/week) & $3[2 \sim 5]$ & $4[2 \sim 4]$ & 0.728 & $4[2 \sim 5]$ & $3[2 \sim 4.5]$ & 0.414 \\
\hline Active & $57(45.6)$ & $12(9.6)$ & \multirow{2}{*}{0.204} & $52(41.6)$ & 17(13.6) & \multirow{2}{*}{0.177} \\
\hline Inactive & $41(32.8)$ & $15(12.0)$ & & $36(28.8)$ & 20816.0) & \\
\hline
\end{tabular}

PA: Physical activity, HBSC-J: Health Behavior School Children in Japanese version, MVPA: Moderate to vigorous PA, VPA: Vigorous PA. 
あった，本邦における先行研究では，Active群は男子74 〜 76\%, 女子 $44 \sim 48 \%$ と報告されて抢り ${ }^{21,22)}$, 本研究は 先行研究と比較し男子は低活動, 女子が高活動である傾 向を示していた：システマティックレビューにて身体活 動量が高い要因として男子であることが含まれている ${ }^{34)}$ ことからも, 本来男子の方が活動量は高いとされている。 本研究は男子の活動量が低い傾向を示しており，一般的 な学童期対象よりも低活動な男子で構成されていたと考 えられる。

運動機能と体格, 身体活動量との関連性 本研究では, 身体機能調査のうち，該当者の多かったしゃがみ込みの 可否, 前屈での指先接地の可否について体格および身体 活動量との関連性を検討した。本研究の結果，しゃがみ 込み不可者は体格指数のローレル指数が高い傾向を示し たが，ローレル指数と身体活動量との間に関連性は認め なかった。肥満傾向な児童にしゃがみ込み不可者が多 かったこととして，本研究では踵が浮かず，後方に転倒 せずに最後までしゃがみ込むことができるかで判断した ことから腹部と大腿部の圧迫などが制限となり肥満傾 向の児童ではしゃがみ込み不可者が多かったと考えられ る。また，しゃがみ込み不可者で，肥満度やローレル指

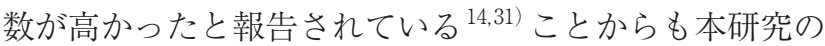
結果は先行研究と同様の傾向を示していた。前屈での指 先接地の可否については体格との関連性を示さなかっ た。各動作と体組成との関連として，しゃがみ込みは体 脂肪率との関連を示し, 前屈は筋肉発達率と関連してい たという報告 ${ }^{35)}$ からも前屈での指先接地はしゃがみ込み と比べ肥満などの体格の影響を受けにくく関連を示さな かったと考えられる。

身体活動量との関連性としては，しゃがみ込み不可者 は身体活動調査HBSC-Jの MVPAの日数㧍よびVPAの 頻度の項目においては有意に低值を示した一方で，VPA の時間およびActive/Inactiveの 2 分類においては有意 な関連を示さなかった。この結果については十分な検討 が必要である。 システマティックレビューによると週 3 ～5 日，中等度～高強度の多種多様な身体活動を 1 日に 30４４分実施することは体脂肪減少に効果があるとされ ている ${ }^{36)}$ 。また，身体活動と肥満との関係として収集さ れた 48 本の報告のうち 38 本で身体活動と肥満に有意な 負の相関を示したとの報告もされている ${ }^{37)}$ 。これらの知 見から身体活動が低い児童は肥満に陥りやすいことが考 えられ，しゃがみ达みなどの動作に影響を及ぼす可能性 が考えられる，そのため，本研究では，しゃがみ込み不可 者にHBSC-JのMVPAの日数抢よびVPAの頻度の項目 で有意な関連が認められたのではないかと考えられる。

一方, 本研究ではローレル指数と HBSC-Jに関連を認 めなかった。本研究でローレル指数が 140 以上であった
26名の内, Active群に11名（42.3\%）属していたことか ら肥満傾向な児童は必ずしも低活動ではないことが明ら かとなった。

本研究の結果から，しゃがみ込みが困難になる要因と して肥満であることに加え，低活動も1つの因子となる 可能性が示唆された，そのため，しゃがみ込みが困難な 児童に対しては, 運動機能の改善のために身体活動の促 進や肥満の改善に関した指導やフォローアップを実施し ていく必要があると考える。

本研究の限界と今後の展望 本研究にはいくつか限界が ある。第一に運動機能測定を可否のみで判断しており, 可動域や制限因子など詳細の評価が行えていない，加え て, 運動器機能のしゃがみ込み, 前屈での指先接地を除 く項目で該当者が少なく関連性の検討は未検証である. 制限因子を考慮した運動機能調査や，対象者を増やして の検討が必要である.

第二に, 本研究では, 身体活動量調査は質問紙を使用 したため，簡便に多くの対象者で測定が可能な一方，正 確性は客観的評価の加速度計の方が優れている。今後は 加速度計を使用した客観的な身体活動量調査もふまえた 上で検討する必要がある。

第三に，対象者が小学校 1 校の高学年であったため地 域による特性が生じた可能性がある，本研究では，過疎 地域における検討であったため都市部など他の地域でも 同様の傾向を示すかは未検討である，今後は，他地域で の検討や 5,6 年生以外の対象者での検討も行っていく 必要がある。

本研究の結果，運動機能の内，しゃがみ込み不可者は 身体活動が低活動な児童や肥満児童が多い可能性があ り，しゃがみ込み不可者へ身体活動や肥満の改善に関す るフォローを行うことが課題解決の一助となる可能性が 示唆された

\section{謝 辞}

本研究にご協力頂きました児童・保護者の皆様，ならび に富岡紀夫氏，増田憲子氏はじめ群馬県 $\mathrm{T}$ 市立 $\mathrm{T}$ 小学校の 関係職員の皆様に深謝申し上げます。

利益相反自己申告：著者全員が利益相反はない．

\section{著者貢献}

著者 S.K，著者 S.H，著者S.Uは研究デザインとプロトコ ルを概念化し，研究施設を決定した，著者S.K，著者S.Hは データの収集を担当した，データの分析，解釈は著者 S.K と 著者S.Uが担当した，草稿は著者S.Kが担当した，すべての 著者は, 原稿を批判的にレビューし, 修正し, 投稿を承認した。 


\section{引用文献}

1）文部科学省. 幼児運動指針ガイドブック. https://www. mext.go.jp/a_menu/sports/undousisin/1319772.htm （閲覧日: 2020年 6 月 4 日）

2) World Health Organization. Global recommendations on physical activity for health. https://www.who.int/ dietphysicalactivity/global-PA-recs-2010.pdf（閲覧日 2020年 5 月 29 日)

3) U.S. Department of Health and Human Service. 2008 Physical Activity Guidelines for Americans. https:// health.gov/sites/default/files/2019-09/paguide.pdf（閲 覧日2020年 5 月 29日)

4) Bull FC, and the Expert Working Groups. Physical Activity Guidelines in the UK: Review and Recommendations. Loughborough University. https://assets.publishing.service.gov.uk/government/uploads/system/ uploads/attachment_data/file/833148/dh_128255.pdf （閲覧日2020年 5 月29日）

5）帖佐悦男, 山口奈美, 河原勝博, 山本惠太郎：学校健診に おける運動器検診の普及に向けて－宮崎方式：なぜ子 供の頃からロコモティブシンドローム予防が必要か . 課題とその対策一, 日本臨床スポーツ医学会誌, $21: 574-$ 580, 2013.

6) 高橋敏明, 内尾祐司, 武藤芳照：小児の運動器 - 運動器 検診の概念と目的 - , Jpn J Rehabil Med 55: 4-8, 2018.

7）スポーツ庁。平成 28 年度全国体力・運動能力調 査結果, 2016. https://www.mext.go.jp/prev_ sports/comp/b_menu/other/__icsFiles/afieldfile/2016/12/15/1380539_02.pdf(閲覧日2020年5月29日)

8）笹川スポーツ財団. 青少年のスポーツライフ・データ 2015, 39-54, 2015.

9）内尾祐司, 高橋敏明, 武藤芳照. 第 1 章 学校健診への運 動器検査導入の経緯と意義・目的, 学校の運動器検診 子どもの身体と障害の診かた, 中外医学社, 2-58, 130140, 2018.

10）文部科学省スポーツ・青少年学校健康教育課. 第 1 章 児童, 生徒, 学生及び幼児の健康診断の実施, 児童生徒等 の健康診断マニュアル（7), 公益財団法人日本学校保 健委員会, 9-72, 2015.

11) 内尾祐司: 学校における運動器疾患・障害の現状と課題, 日本整形外科学会雑誌, 91:243-252, 2017.

12）山口奈美, 山本惠太郎, 河原勝博, 石田康行, 田島卓也, 帖佐悦男：子どもからのロコモ予防の重要性一運動器 検診を通してー, 日本臨床スポーツ医学会誌, 22: 250253, 2014.

13) Kamada M, Abe T, Kitayuguchi J, Imamura F, Lee IM, Kadowaki M, Sawada SS, Miyachi M, Matsui Y, Uchio Y. Dose-response relationship between sports activity and musculoskeletal pain in adolescents. Pain 157: 1339-1345, 2016.

14）田中誠智, 藤堂 萌, 中村雅俊, 森原徹, 北條達也：小学生 に対する運動器検診結果とローレル指数の関係, Doshisha Journal of Health \& Sports Science 7: 23-34, 2015.

15）総務省統計局. 平成 27 年国政調查. https://www.estat.go.jp/stat-search/files?page $=1 \&$ layout $=$ datalist \&touke $=00200521 \&$ tstat $=000001080615 \&$ cycle $=0 \&$ tclass $1=000001089055 \&$ tclass $2=000001089057 \&$ tcla ss $3=000001089067$ （閲覧日 2020年 5 月 29日）

16）富岡市ホームページ.小・中学校児童生徒数につ いて. https://www.city.tomioka.lg.jp/www/contents/1000000000913/index.html（閲覧日 2019年 5 月 29日）

17) 西田 誠, 船橋 徹：肥満判定指数 [BMI (Kaup 指数), Rohrer 指数, Broca法]による肥満度判定とその妥当性, 日本臨床, 67: 301-306, 2009

18）片岡邦三：体格指数法, 日本臨床, 53: 147-153, 1995.

19) Tanaka C, Kyan A, Takakura M, Olds T, Schranz N, Tanaka M, Tanaka S. The Validity of the Japanese Version of Physical Activity Questions in the WHO Health Behavior in School-aged Children (HBSC) Survey. Res Exerc Epimiol 19: 93-101, 2017.

20) Booth ML, Okely AD, Chey T, Bauman A. The reliability and validity of the physical activity questions in the WHO health behaviour in schoolchildren (HBSC) survey: a population study. Br J Sports Med 35: 263267, 2001

21）高倉 実, 小林 稔, 宮城政也, 小橋川久光, 加藤種一：児 童における身体活動質問項目の信頼性と妥当性：WHO Health Behaviour in School-aged Children Survey 日本 語版の場合, 琉球大学教育学部紀要, 69: 199-205, 2006.

22）岡崎勘造, 鈴木宏哉, 坂本 譲, 佐々木桂二：質問紙法に よる小学生の身体活動量評価の有用性, 体力科学, 66 : 407-416, 2017.

23）群馬県教育委員会, 群馬県医師会. 学校における運動 器検診マニュアル. https://www.pref.gunma.jp/contents/100016277.pdf（閲覧日2020年 9 月 30 日）

24）林 承弘：子どもロコモと生活習慣－運動器検診のめざ すもの, 臨床栄養, 128: 460-464, 2016.

25) Cain KL, Sallis JF, Conway TL, Van Dyck D, Calhoon L. Using accelerometers in youth physical activity studies: a review of methods. J Phys Act Health 10: 437450, 2013.

26) Trost SG, Pate RR, Sallis JF, Freedson PS, Taylor WC, Dowda M, Sirard J. Age and gender differences in objectively measured physical activity in youth. Med Sci Sports Exerc 34: 350-355, 2002.

27) Ishii K, Shibata A, Adachi M, Nonoue K, Oka K. Gender and grade differences in objectively measured physical activity and sedentary behavior patterns among Japanese children and adolescents: a crosssectional study. BMC Public Health 15: 1254, 2015.

28) 林 承弘：健康診断 (運動器検診) 健康診断で体が硬い と判定されたら,チャイルドヘルス, 20: 185-189, 2017.

29）津島愛子, 三村由香里, 本田浩江, 萩原真菜, 桑島若菜, 能海佳奈：小学生における運動器検診の結果と課題, 岡 山大学大学院教育学研究科研究集録, 164: 41-47, 2017.

30）柴田輝明：運動器検診によるスポーツ障害の予防, 小児 科臨床, 68: 205-212, 2015.

31）滝澤恵美, 小林育斗, 川村紗世, 岩井浩一：児童における しゃがみ動作の可不可および関節間協調性に関連する 要因, 理学療法学, 46: 225-232, 2019.

32）可西泰修, 鎌田浩史, 眞下苑子, 葍科侑希, 塚越祐太, 田中 健太, 山崎正志, 宮川俊平, 白木 仁 : 運動器検診結果加 
らみた小学生の運動器の特徵, 日本臨床スポーツ医学会 誌, 27: 66-75, 2019.

33) 文部科学省. 令和元年度学校保健統計 (学校保健統計調 査報告書). https://www.mext.go.jp/content/20200319mxt_chousa01-20200319155353_1-3.pdf（閲覧日 2020 年 9 月 30 日)

34) Van Der Horst K, Paw MJ, Twisk JW, Van Mechelen W. A brief review on correlates of physical activity and sedentariness in youth. Med Sci Sports Exerc 39: 1241-1250. 2007.

35) 明渡陽子, 上杉宰世, 石井雅幸 : 高学年児童の運動器 (骨
と筋肉）発達と生活習慣との関連, 大妻女子大学家政系 研究紀要, 55: 57-68, 2019.

36) Strong WB, Malina RM, Blimkie CJ, Daniels SR, Dishman RK, Gutin B, Hergenroeder AC, Must A, Nixon PA, Pivarnik JM, Rowland T, Trost S, Trudeau F. Evidence based physical activity for school-aged youth. $J$ Pediatr 146: 732-737, 2005.

37) Jiménez-Pavón D, Kelly J, Reilly JJ. Associations between objectively measured habitual physical activity and adiposity in children and adolescents: Systematic review. Int J Pediatr Obes 5: 3-18, 2010. 